\title{
“UMA JUVENTUDE DIGNA É A CONDIÇÃO DO CRIAR”: ROMANTISMO E FORMAÇÃO EM WALTER BENJAMIN
}

Priscilla Stuart da Silva

\begin{abstract}
RESUMO
Este artigo discorre sobre o sentido de religiosidade na formação da juventude segundo Walter Benjamin. Através de alguns escritos sobre o tema produzidos entre 1911-1919, principalmente em Metafísica da juventude, o filósofo buscou evidenciar como a necessidade da reforma espiritual é premente em sua época e a ideia da crítica do jovem pela sua escrita é indicada como tarefa (Aufgabe). A escrita de diários, explorada no ensaio mencionado, é a forma íntima do jovem elaborar sua própria singularidade, constituindo-se como um campo semântico na Filosofia da Educação. Ao lado da produção em revistas acadêmicas e do uso da palavra em agremiações estudantis - atividades exercidas por Benjamin à época -, constituem-se como elementos de formação mais geral (Bildung), incluídas também em suas reflexões sobre a prática estudantil.
\end{abstract}

Palavras-chave: Formação. Religiosidade. Benjamin

\section{“A DIGNIFIED YOUTH IS THE CONDITION OF CREATING”: ROMANTICISM AND EDUCATION IN WALTER BENJAMIN}

\begin{abstract}
This article discusses the sense of religiosity in the formation of youth, according to Walter Benjamin. Across some writings on the subject produced between 1911-1919, mainly in the Metaphysics of the youth, the philosopher sought to show how the need for spiritual reform is urgent in his time, and the idea of criticism of the young through the act of writing is indicated as a task (Aufgabe). The writing of diaries, explored in the aforementioned essay, is the young's intimate way of elaborating his own uniqueness, constituting itself as a semantic field in the Philosophy of Education. Along with the production in academic journals and the use of the word in student associations - activities carried out by Benjamin at the time -, they constitute elements of more general education (Bildung), also included in his reflections on student practice.
\end{abstract}

Keywords: Formation. Religiosity. Benjamin 
A relação de Benjamin com a educação é significativa. Como era um grande colecionador de brinquedos e livros infantis, fez da coleção um tema filosófico, de reflexão. Muitos de seus aforismos e ensaios mais conhecidos, incluindo "Brinquedos e jogos", "Princípios verdejantes: novos elementos a respeito de cartilhas lúdicas", "A hora das crianças: narrativas radiofônicas", "Elogio da boneca", "Pestalozzi em Yverdon”, "Infância em Berlim”, entre outros, conferem um modo não instituição de lidar com a formação, cercado de ideias transgressoras e progressistas, indicando um pensador que estava preocupado com o humano em todas as suas experiências e espaços. E embora esses ensaios posteriores de seu pensamento ${ }^{1}$ já estivessem marcados por um viés menos idealista, é possível identificar neles a mesma marca de um filósofo preocupado com os acontecimentos de sua realidade, pois através de sua própria vida descobrimos vestígios, referências e críticas ao seu tempo histórico.

Nos primeiros ensaios de Benjamin encontramos reflexões sobre a formação envolvidas pelo tema da religião, da moral e do sentido do transcendente. Para Ballester, o desenvolvimento da esfera do espírito na vida da juventude escolar é parte constitutiva do sentido de educar e, por extensão, da formação do jovem (BALLESTER, 2016, 181).

Os ensaios da juventude de Benjamin certamente causam um estranhamento pelo uso de termos pouco convencionais, encontramos expressões como religião, comunidade, espiritualidade, messianismo, destino. É importante demarcar o uso feito aqui de todas essas denominações. Por isso, para facilitar a compreensão, serão chamados de religiosidade todos esses termos utilizados nos ensaios da juventude aqui utilizados, os quais, de maneira geral, demarcam o terreno do sagrado, enquanto que o sentido de religião é pensado desde o ponto de vista subjetivo e não institucional. Acredita-se que Benjamin traduzia todos esses termos pela expressão religiosidade, como fazia o próprio Schlegel, ao dizer que "a relação do verdadeiro artista e do verdadeiro homem para com seus ideais também é, inteiramente, religião" (SCHLEGEL,

${ }^{1}$ Cf. BENJAMIN, Walter. Reflexões sobre a criança, o brinquedo e a educação. São Paulo: Ed. 34/Duas Cidades, 2009.

Doutora em Educação. Professora substituta na Universidade Federal de Santa Catarina. Brasileira, residente em Florianópolis - SC. Email: priscillastuarts@gmail.com 
1997, p. 129). O filósofo também marcará o uso não convencional do termo ao usar a expressão "religião do espírito" (BENJAMIN, 2013b, 55; cf. G.S. II, 1, 44).

"Toda luta com os derradeiros valores é religiosa", dirá Benjamin, e como se está tratando de um tema caro à educação, o sentido do sagrado é básico para este projeto, já que "a formação da essência humana, a controvérsia do homem com o mistério que dá sentido à vida constitui, no fundo, um processo religioso e até mesmo um crescimento e atuação do próprio divino na alma". No fundo, o que se busca é um sentido para a vida humana que transcenda a cotidianidade e o transitório da existência, pois é pela religiosidade que parece existir um centro quando o filósofo explora as diversas esferas do universo juvenil. Logo, "todo ponto de vista vital, toda recepção e revelação, todo julgamento moral, todo sentimento vital é reflexo do divino na alma, e irradiação, no mundo, do Deus que foi encontrado" (SPRANGER, 1970, 401).

Desta forma, ao refletir sobre as expressões do sagrado e da religiosidade no pensamento do jovem Benjamin, é possível começar pelo sentido ou concepção de comunidade, que indica uma marca persistente em seus primeiros ensaios e que parece contrapor-se à ideia de sociedade.

Quando o filósofo menciona a palavra "sociedade", percebe-se um tom carregado de crítica, como no ensaio Veladas literárias estudantis: "Ninguém duvida que a arte irá revelar toda a letargia, todo o afastamento do espírito, toda a deficiência que existe na sociedade estudantil" (BENJAMIN, 2010d, 70; cf. G.S. $I I, 1,68)$. Como panaceia, ele vai enxergar na comunidade uma solução, pois é nela que será possível cultivar a sinceridade e o sentido da amizade. Mas qual seria o sentido de comunidade para os jovens?

O simples desenvolver-se enquanto comunidade representa "uma expressão de transbordante anseio pela Vida em sua totalidade". E ainda: "a comunidade é fim e fonte de Vida", de modo que a juventude torna-se plena em sua totalidade somente quando percebe, em si mesma, que "o parentesco e a comunidade de toda a vida do mundo, não podem ser exercitados totalmente a não ser em comunidade. E, em uma comunidade pura, nada podemos criar que não intensifique o poder, o sentido e o valor da Vida" (BUBER, 1987, 34): por isso, Benjamin afirma que "uma juventude digna é a condição do criar" (BENJAMIN, 2009a, 46). Segundo Buber, "vida e comunidade são os dois lados 
de um mesmo ser". E essa perspectiva é interessante e muito próxima à de Benjamin, pois o que ele visava condiz mais com um tipo de associação humana preocupada não com a "regulamentação externa, mas formação interna", tal como defende Buber (BUBER, 1987, 34, 37).

Benjamin, por sua vez, ao defender a vida humana pautada pela juventude como redentora, acredita que assim o sagrado se revelará (BENJAMIN, 2009c, 29; cf. G.S. II, 1, 73). O nascimento dessa juventude é algo que emerge do caos, é o novo, e, por isso, "não pode ser imposto de fora por grupos humanos ativos; ela deve emergir do interior em cada tempo e lugar. Somente quando o alegre ritmo da vida vencer a regra". E isso significa a promessa de uma juventude que representa uma cultura nova, de vanguarda, que está nascendo, pois "somente quando a eternamente fluente e variável lei interna da Vida substituir a convenção morta, a humanidade estará livre de coerção do vazio e do falso, só então encontrará a verdade". "A nova comunidade", da juventude, "quer preparar ativamente o caminho para esta verdade" (BUBER, 1987, 37-38).

Para caracterizar melhor a diferença marcante entre comunidade e sociedade, não se pode deixar de pensar em Tönnies, para quem "a comunidade é a vida comum, verdadeira e durável; a sociedade é somente passageira e aparente. E, em certa medida, pode-se compreender a comunidade como um organismo vivo, e a sociedade como um agregado mecânico e artificial" (TÖNNIES, 1973, 98).

Essa associação de jovens unidos por um bem comum, de compartilhar os mesmos desejos e vontades, promove ou possibilita o cultivo de valores semelhantes, fruto da relação natural, unida, pura e espontânea, motivada pelo simples propósito de realizar trocas, sem coerção, tudo pela busca da unidade que será promovida pela própria (auto) formação.

No movimento da juventude ${ }^{2}$, grupo a qual pertencia o filósofo, era de vontade comum a discussão sobre valores clássicos proporcionada pelas

\footnotetext{
2 O Movimento da Juventude Livre Alemã data do início do século XX, tendo sido fundado, precisamente, em 4 de novembro de 1901, nos subúrbios de Berlim. Os fundamentos teóricos e raízes históricas e culturais da organização remontam a três influências decisivas: ao movimento em que Goethe e Schiller foram os pioneiros, o Sturm und Drang; ao Burschenschaft (forma tradicional de corporação estudantil alemã) e ao romantismo alemão, que fora decisivo para construir os princípios ideológicos do movimento jovem (LAQUEUR, 2011, 3).
} 
leituras de Platão, por exemplo. Ou seja, os laços que os uniam - e que Benjamin utiliza como parâmetro para defender os valores das associações comunitárias entre jovens - eram suas afinidades em cultivar a vida do espírito.

Spranger, ao descrever os elementos que caracterizam esses movimentos, faz assertivas que corroboram com as defendidas por Benjamin, pois, para se pensar na nova cultura da juventude, é importante perceber a diferença de propósitos: "Parece mesmo não tratar-se de valores culturais inteiramente próprios (pois os bens culturais transcendem as gerações), mas de formas sociais nas quais se deseja viver e atuar dentro da cultura comum" (SPRANGER, 1970, 208).

Esse projeto de juventude comunitária é parte do ideal romântico de juventude de Benjamin pautado pela postura da franqueza. Somente com esse romantismo será possível perceber "os nexos espirituais" presentes na "existência" e no "comportamento cotidiano" (BENJAMIN, 2013b, 56-57; cf. G.S. II, 1, 46-47). Ser jovem, segundo ele, "é ter fé" e "sentir-nos como jovens pela graça de Deus, se tivermos esse entendimento" (BENJAMIN, 2013b, 53; cf. G.S. II, 1,42).

Possivelmente essa expressão denota um senso universal, remetendo a um sentido do todo, como afirma José Miranda Justo ${ }^{3}$ ao interpretar o termo "católico" em Novalis. Com a ideia de universal, cada jovem "vale por milhares" (BENJAMIN, 2013b, 53; cf. G.S. II, 1, 42), e assim fica representado o "homem completo", já que sua realização se consolida quando habita "ao mesmo tempo, por assim dizer, em vários lugares e em vários homens". Portanto, "forma-se aqui então a verdadeira, a grandiosa presença do espírito - que faz do homem propriamente um cidadão do mundo e o estimula a cada instante da vida por intermédio das mais benéficas associações" e "de uma atividade refletida" (NOVALIS, 2006, 66).

Deus ou o divino mencionado pode também ser pensado como "aquilo que jorra do amor pelo puro ser e devir eterno, amor que é mais alto do que toda

\footnotetext{
3 "A utilização que Novalis faz do adjetivo "católico" deve ser entendida sobretudo em sentido etimológico; o étimo grego significa "universal". Na altura em que Novalis redige este texto não se manifestara ainda no círculo de Jena nenhuma tendência para a conversão ao Catolicismo; a conversão de Karl von Hardenberg (irmão de Novalis) e de Friedrich Schlegel ocorre apenas em 1807, 1808. (JUSTO, 2006, 31, nota de rodapé).
}

Doutora em Educação. Professora substituta na Universidade Federal de Santa Catarina. Brasileira, residente em Florianópolis - SC. Email: priscillastuarts@gmail.com 
poesia e filosofia". Um amor mais enobrecedor porque "há uma divindade plácida sem a força trituradora do herói e a atividade formadora do artista. Aquilo que é ao mesmo tempo divino, perfeito e acabado e grande, é completo" (SCHLEGEL, 1997, 132).

A juventude como expressão desse divino é a representação da espera do espírito, "da nova realidade", em que "um ideal utópico de juventude" surgirá. Ser jovem é estar com o "olhar puro, livre e disponível para a abstração do espírito", e ter também a capacidade de livrar-se de todo "pensamento determinado". Por isso é que somente do interior do espírito ou "da dimensão mais íntima de sua organização da qual deve proceder tudo o que há de pertencer à verdadeira vida do homem e sempre constituir nele um impulso ativo e efetivo" (SCHLEIERMACHER, 1990, 90).

A juventude que usa livre e autonomamente o pensamento vai ao encontro do célebre ensaio kantiano O que é o iluminismo? (1784), referência importante na formação benjaminiana. Nele, Kant defende um uso público e autônomo do pensamento, qualificando esse uso de "maioridade" - uma categoria juvenil, o esclarecimento da razão (KANT, 2015, 9-18). Tanto Benjamin quanto Kant, nesse caso, fazem apelo à educação e à liberdade. Afinal, a liberdade, para o filósofo de Berlim, é "o maior bem histórico. Porque a liberdade não é um programa, mas a vontade para um programa, isto é, uma mentalidade", ou ainda, "a primeira necessidade no mundo das forças" (BENJAMIN, 2010c, 60-61; cf. G.S. II, 1, 59-60).

A discussão sobre a liberdade aponta para o termo Bildung, que surgiu com Herder. Logo, seu sentido lato aproxima-se mais da ideia de "autoformação" e "atuação viva" do que da "educação e ensino" institucionais. É importante revisar a tradição dessa palavra para entender o contexto espiritual e comunitário em que Benjamin utiliza o termo. A constante menção à esfera espiritual é uma referência a essa formação que o filósofo pensou, qual seja, a do desenvolvimento espiritual e ético do indivíduo. "A Bildung, segundo Herder, é o conceito central para todos os que estão empenhados no desenvolvimento físico, psíquico e intelectual do ser humano” (BOLLE, 1997,17-18).

Benjamin é fruto de "uma geração que pretende reinventar o sentido da existência dos laços sociais de comunidade" porque, frente à constante 
fragmentação da sociedade desarticulada, "o sagrado perde cada vez mais importância e é substituído por uma visão desencantada do mundo" (CANTINHO, 2016, 11). O resultado só pode ser a reinvenção de novas formas de interação em sociedade na tentativa de recuperar o sentido pedagógico e filosófico de pertencimento a certos grupos sociais. Desta forma, a juventude, enquanto comunidade, é defendida como um modo específico de existência, mas também com ressonâncias na formação humana em geral. Somente na comunidade se realiza o verdadeiro sentido da solidão, porque apenas através dela consegue-se atingir o "florescimento dos sentidos superiores, e daí que um convívio demasiado amplo dos homens uns com os outros tenha que asfixiar muitas das sementes sagradas e afugentar os deuses que desprezam o tumulto inquieto das sociedades distrativas" (NOVALIS, 2006, 32).

Em O posicionamento religioso da juventude, o despertar da juventude enquanto ideia ou movimento - aqui ainda não havia acontecido o rompimento com o grupo mencionado acima - dar-se-á pelo sentido do religioso. Mediante um tom profético e cheio de esperança, o filósofo conjuga juventude, formação e religião, deixando claro que não há qualquer relação institucional ou ideológica com essa juventude que está despontando. Sua fé parte do princípio de que algo novo nasce e se liberta do que antes o acorrentava. A religião significa, em seu sentido mais arcaico, etimológico e primário, "o caminho que a geração jovem percorre em seu processo de formação" e "tal caminho de formação permanece vazio e penoso sem o ponto onde ele se bifurca numa opção decisiva. Esse ponto deve ser comum a toda uma geração, e lá se ergue o templo de seu Deus". Já que as escolhas humanas estão fadadas a se dessacralizar, as escolhas da juventude necessitam do sentido do sagrado contido nas coisas do mundo. A revelação do sentido do sagrado, inestimável a um presente que inspira vivências ${ }^{4}$ enriquecedoras, dependerá do "momento em que a vontade comum

\footnotetext{
${ }^{4} \mathrm{~A}$ ideia de vivência no jovem Benjamin tem um sentido positivo, expressando a ideia de potência de vida da juventude, diferente de seu oposto, o termo "experiência". "Numa nota escrita provavelmente em 1929, Benjamin lança um olhar retrospectivo a este texto de 1913: Num de meus primeiros ensaios mobilizei todas as forças rebeldes da juventude contra a palavra "experiência". E eis que agora essa palavra tornou-se um elemento de sustentação em muitas de minhas coisas. Apesar disso, permaneci fiel a mim mesmo. Pois o meu ataque cindiu a palavra sem a aniquilar. O ataque penetrou até o âmago da coisa" (Cf.: MAZZARI, M. Nota de rodapé. In: BENJAMIN, W. Reflexões sobre a criança, o brinquedo e a educação. São Paulo: Editora 34, 2009, 21).
}

Doutora em Educação. Professora substituta na Universidade Federal de Santa Catarina. Brasileira, residente em Florianópolis - SC. Email: priscillastuarts@gmail.com 
de escolha tiver alcançado a máxima tensão" (BENJAMIN, 2009c, 27-28; G.S. II, 1, 72-73).

É importante também o destaque dado a Deus em $O$ posicionamento religioso da nova juventude e em outros ensaios do período, cuja alusão é resultado da imersão em si mesmo em busca da própria singularidade, constituindo-se mais como "um deus como sua intuição" (SCHLEIERMACHER, 1990, 84), uma forma de o jovem medir a própria religiosidade.

A aspiração por Deus ou pelo absoluto é a forma autêntica do jovem se comunicar com a própria transcendência, que o levará para um caminho de vivências ou experiências nas quais enxergará a totalidade em cada coisa ou objeto contemplado. Esse absoluto, pelo que se pode interpretar, é um absoluto de matiz filosófico-educacional, que deverá conduzir o jovem à própria formação. Lessing - dramaturgo importante da Alemanha e para o movimento Sturm und Drang -, em um jogo de palavras com relação à dimensão espiritual humana, definia a educação como "uma revelação que acontece ao indivíduo" e a revelação como uma "educação que ainda acontecia ao gênero humano" (LESSING, 1982, 574). Talvez este seja o sentido de absoluto pensado por Benjamin.

Em Sobre a religião (1799), ensaio importante para o romantismo alemão, Schleiermacher realiza uma análise peculiar sobre o tema. Fora dos limites institucionais, discorrerá sobre a religião a partir do ponto de vista do indivíduo, como um sentimento ou aspiração ao infinito, inatos ao humano. Uma proximidade evidente com as referências religiosas de Benjamin, que o mencionará em seu Diálogo sobre a religiosidade.

Em Ensino de moral, a religiosidade e o sentido comunitário da existência são fatores determinantes à formação ética. Nesse ensaio, de influência kantiana, Benjamin chegará a uma conclusão diferente do filósofo prussiano, ao reconhecer a necessidade de exemplos práticos e conteúdos reais para que a lei ou a norma ética produza efeitos na educação humana. O sentimento de religiosidade - porque se trata definitivamente de um sentimento - será o critério 
ou o elemento que determinará "como a lei ética recebe os seus conteúdos concretos" (BENJAMIN, 2009b, 15; cf. G.S. II, 1, 51).

Na Metafísica da juventude o destino é mais uma face da religiosidade. Benjamin o define como o "contramovimento das coisas no tempo do eu" (BENJAMIN, 2010a, 105; cf. G.S. II, 1,102). Essa noção pode ser lida similarmente como Rilke afirma em suas Cartas a um jovem poeta (1929), ou seja, que "se aprenderá automaticamente que vem de dentro dos homens aquilo a que damos o nome de destino, não se trata de algo que entra neles partindo de fora" (RILKE, 2016, 76).

A própria ideia de metafísica no título do ensaio fornece pistas para o modo como o texto deve ser interpretado e compreendido. Em um primeiro plano, é preciso ter em conta que Benjamin fará uma espécie de defesa do modo de ser próprio do jovem, enquanto que a interpretação do leitor, nesse caso, ficará em segundo plano.

A expressão "metafísica" ainda sugere "revelação", um sentido previamente dado. Aqui, a argumentação parte da própria força interna da palavra revelada, a exemplo de um poema; já a interpretação fica resguardada a um segundo plano. E a metafísica, em seu sentido amplo, é o caráter mais rudimentar de algo, e, nesse caso, Benjamin "revela" as palavras do ensaio de um modo muito peculiar, por vezes hermético e com um tom inspirado.

Em Diálogo sobre a religiosidade do nosso tempo, a recuperação do sentido do religioso é veemente, uma vez que se está "em meio a uma crise religiosa", sendo que "a essência da crise" é a falta de "autonomia moral": "a religião é incompatível com o progresso" - talvez por isso ela não seja um elemento que combine com a época atual. É ainda "do seu feitio acumular todas as forças prementes e expansivas na interioridade num único ponto alto sublime. A religião é a raiz da inércia. É a sua santificação". Ser religioso é um sentimento incomum, prova disso é que "não mais observamos em lugar algum o persistir". Falta o sentido da totalidade, "por sermos deploravelmente pobres em valores, isolamos tudo" (BENJAMIN, 2013a, 32; cf. G.S. II, 1, 17).

Pensa-se que essa inércia significa aquele sentido da mônada, em que o aparente significado de estar imóvel, estático, contém, na verdade, uma potência infinita de sentidos. Ainda para Benjamin, "o objeto da religião é a infinitude" 
(BENJAMIN, 2013a, 43; cf. G.S. II, 1, 27). A demonstração do caráter não institucional da religião desenvolvida em sua obra aponta para a necessidade de a vida humana buscar novas formas de encontrar o conhecimento e de relacionar-se com as vivências individuais.

Pelas novas gerações, encontra-se esse sentido do religioso: "Aos poucos, uma nova geração terá a ousadia de voltar a examinar a si própria, e não só por meio de seus artistas". E essa geração conseguirá perceber que no presente existe:

pressão e inverdade que agora nos coagem. Ela reconhecerá o dualismo de moralidade social e personalidade. Dessa necessidade brotará uma religião. E ela será necessária porque nunca antes a personalidade esteve enredada tão sem esperanças no mecanismo social (BENJAMIN, 2013a, 41; cf. G.S. II, 1, 26).

Esse pensamento sugere que, através da religião ou do sentido do religioso, do maravilhoso, é possível enxergar o extraordinário, pois somente pela religião existe a possibilidade de encontrar "um novo fundamento e uma nova nobreza à vida cotidiana, à convenção" (BENJAMIN, 2013a, 45; cf. G.S. II, 1, 29). Ou ainda, pode-se alcançar aquilo que Spranger chamará de "emoção estética" (SPRANGER, 1970, 388) proporcionada por esse novo sentido do religioso na esfera da existência humana. A maior prova de que sua religiosidade está fora dos muros institucionais é sua afirmação segundo a qual a religião é "purificação e santificação solitárias" (BENJAMIN, 2013a, 45; cf. G.S. II, 1, 29). Afinal, desfrutar o sentido dessa afirmação é algo de natureza individual e incomunicável em primeira instância.

O significado ou necessidade do religioso ocorreu no momento em que Kant realizou a separação entre "a sensualidade e o entendimento e quando reconheceu a supremacia da razão prática, da razão moral, em tudo o que acontece. A humanidade havia despertado de seu sono desenvolvimentista, e esse despertar simultaneamente a privou de sua unidade" (BENJAMIN, 2013a, 47-48; cf. G.S. II, 1, 31-32). Ou seja, com Kant, o homem foi separado, e em seu interior só encontrou o abismo. Essa separação radical negligenciou outras esferas da experiência e da vida humana como um todo, tais como a religiosa e 
a sagrada ${ }^{5}$. Essa afirmação vai ao encontro de outro ensaio da juventude de Benjamin, a saber, Sobre o programa da filosofia futura (1917), que, grosso modo, pretende mostrar os limites da filosofia kantiana que não consegue abarcar um conceito de "experiência superior", mais profunda, que inclua as instâncias da vida religiosa e metafísica. Mesmo com seus limites, toda filosofia deve pautar-se pelas ideias e pelo sistema kantiano, mas procurar, ao mesmo tempo, dar conta de seus limites.

E, por fim, Benjamin encerra o diálogo afirmando que só será possível recuperar aquela unidade, da qual o sentimento religioso carece hoje, através da sinceridade e da humildade, pois somente assim nascerá um novo tipo de ser humano (BENJAMIN, 2013a, 50; cf. G.S. II, 1, 34). Pelos outros ensaios do período, pode-se afirmar que é o jovem o responsável pela nova perspectiva humana da realidade e da experiência.

Por isso, diante do vínculo que se procurou estabelecer entre juventude e religiosidade -, a noção de juventude, carregada de simbolismos românticos e de esperança para o futuro, refere-se à ideia do jovem como o "messias" da relação filosófico-pedagógica. O jovem como aquele que está à espera do espírito encontra, nesta espera, o lugar de descobertas de redenção do presente.

\section{A escrita de si em Metafísica da juventude}

Metafísica da juventude é um ensaio importante do início do pensamento de Benjamin, bastante marcado pela concepção idealista de mundo indicado tanto pelos temas trazidos (o tempo, o eu, a concepção de linguagem) como pela escrita metafórica, alusiva, carregada de misticismo e poesia. Neste e em outros ensaios do período, compreendidos entre 1911 e 1919 como percebemos acima, Benjamin está preocupado com a realidade da juventude em meio à atmosfera histórico-político se desenhando, a Primeira guerra mundial e diante de reformas

\footnotetext{
${ }^{5}$ Similar a essa ideia, em Experiência e pobreza e $O$ narrador, Benjamin perceberá a ausência do elemento épico na vida, interpretando-a com o advento do Romance como gênero, no qual predomina a vivência (Erlebnis), que é a atrofia da experiência e que não vincula mais a história humana pessoal à memória. No gênero Romance, o leitor solitário não dispõe mais dos vínculos com as narrativas clássicas próprias do contador de histórias, do ouvinte e dos gestos da fala, acionando memória e experiências compartilháveis.
}

Doutora em Educação. Professora substituta na Universidade Federal de Santa Catarina. Brasileira, residente em Florianópolis - SC. Email: priscillastuarts@gmail.com 
técnicas realizadas em seu ambiente acadêmico. Neste mesmo ensaio, escrito precisamente entre 1913 e 1914, as tensões sociais e políticas estavam especialmente maiores em meio à iminência da Guerra, e no meio estudantil o ambiente era ambíguo, pois parte do grupo, o Movimento da juventude a que Benjamin pertencia, era favorável ao combate, já o filósofo posicionava-se claramente na ala mais radical e contrário à Guerra.

Junto a essa posição política, Benjamin defendia uma visão espiritual e idealista de juventude. O tema da tradição, por exemplo, aparece como o confronto entre o presente, o passado e o futuro na sua dimensão mais geral, histórica, motivando em Benjamin um debate que perdurará, sobretudo, em sua obra da maturidade. Mas é no ensaio Metafísica da juventude que encontramos uma concepção romântica da qual tudo que se realiza no presente é fruto dos antepassados. Ao mencionar a ideia de ruína, o filósofo percebe que os humanos estão pesados, pois carregam, simbolicamente, muito do peso do passado em seus discursos, falas, diálogos. Em toda a conversação, segundo ele, permanece o lamento por algo que se escapa hoje, "a grandeza de tudo perdido". Conduzido por uma linguagem metafísica e poética, constata-se um indício daquilo que o filósofo irá expor, mais tarde, em $O$ narrador e Experiência e pobreza, a saber, o vazio do presente frente a um passado elaborado como ruína. A linguagem ou conversação - seção do ensaio Metafísica da juventude - faz com que se entre em um horizonte de diálogo com a tradição remota (BENJAMIN, 2010a, 93-94; cf. G.S. II, 1, 91).

De acordo com Seligmann-Silva (SELIGMANN-SILVA, 1999, 26), a ideia de um retorno à unidade dos homens, segundo os românticos de Jena, em que não há separação entre as diversas esferas que os constituem, corresponde à volta de uma linguagem originária a que todos compartilhavam antes da "queda". Essa discussão está relacionada à filosofia da linguagem de Benjamin, resgatada de Novalis e Schlegel, na qual ambos afirmavam ser a língua a própria manifestação do espírito do mundo, dom fornecido por deus. Antes da queda, todos, magicamente, se comunicavam com os seres vivos em geral, mas depois, incorporaram um tipo de comunicação instrumental. É, portanto, o caráter mágico, transcendental e formativo - fruto da relação unitária que os humanos 
tinham com sua linguagem -, que é invocado quando se fala em comunicação. Mas como isso pode se relacionar à escrita do jovem?

Diferente de uma linguagem utilizada simplesmente para comunicar fatos e informações, por exemplo, a escrita no diário poderia indicar uma forma de linguagem pura, na qual a própria linguagem indicada se comunica como manifestação da pura vida do jovem, de sua vivência. $E$ isso não significa que ela seja um meio para expressar essa singularidade, mas ela é confundida com esse próprio eu que se expressa. Já na primeira frase de seu ensaio da juventude, Sobre a linguagem em geral e sobre a linguagem do homem, Benjamin afirmará que "toda manifestação da vida espiritual humana pode ser concebida como uma espécie de linguagem" (BENJAMIN, 2011, 49; cf. G.S.II, 1, 140). Como maneira de revelar o caráter espiritual da própria vida, ele ainda dirá que a linguagem "significa o princípio que se volta para a comunicação de conteúdos espirituais" (BENJAMIN, 2011, 49-50; cf. G.S.II, 1, 140). E quando afirma que "não há evento ou coisa, tanto na natureza animada, quando na inanimada, que não tenha, de alguma maneira, participação na linguagem, pois é essencial a tudo comunicar seu conteúdo espiritual” (BENJAMIN, 2011, 51; cf. G.S.II, 1, 140-141), não se poderia dizer que o jovem, ao se autorrepresentar no diário, estaria comunicando sua substância espiritual ${ }^{6}$ ?

Expressando essa concepção romântica da linguagem, Benjamin já pensa em uma crítica ao modo de enxergar a linguagem como mera ferramenta linguística. No caso dos diários, poder-se-ia especular que ali as palavras são expressões de algo maior, destituídas de seu caráter informativo, pois "nela [na linguagem] todas as palavras são elevadas à categoria de nomes próprios, tornam-se mônadas numa linguagem que se autolegisla e que está liberada de ter que servir" (SELIGMANN-SILVA, 1999, 32, grifo do autor).

Partindo, então, para o momento em que o filósofo trata do diário, a necessidade da reforma espiritual e sua concretização instaura uma quebra na ordem da atrofia do sentido da educação e do empobrecimento da cultura que

\footnotetext{
6 "O homem comunica sua própria essência espiritual na sua língua. Mas a língua do homem fala em palavras. Portanto, o ser humano comunica sua própria essência espiritual (na medida em que ela seja comunicável) ao nomear todas as outras coisas (BENJAMIN, 2011, 54; cf. G.S.II, 1, 143).
}

Doutora em Educação. Professora substituta na Universidade Federal de Santa Catarina. Brasileira, residente em Florianópolis - SC. Email: priscillastuarts@gmail.com 
acomete as instituições formativas. Contra isso, combatendo esse esgotamento do significado mais geral de cultura, o exercício da escrita como crítica transforma-se em tarefa (Aufgabe). A escrita de diários, presente na Metafísica da Juventude, é a forma íntima do jovem elaborar sua própria singularidade. Tanto a escrita em revistas acadêmicas, como Benjamin fazia enquanto estudante, quanto o uso da palavra em agremiações estudantis, são ofícios agregadores da busca pelo sentido da formação mais geral, e ambos são igualmente importantes para entender sua concepção de formação da juventude.

A juventude e sua realidade, seus anseios, paixões, dúvidas e descobertas são coisas presentes no conteúdo do diário, mas algo está sendo marcado, o que aparentemente não é possível enxergar: os fundamentos da ideia, da natureza do que é a juventude. O diário, de alguma forma, inaugura um campo de significados do que é ser jovem. Pela primeira vez, é possível pensá-la como objeto de estudos da perspectiva filosófico-educacional. Ao tratar do tema da juventude, entra-se em campos de saberes que perpassam áreas como a sociologia, a pedagogia, a filosofia, a história e a psicologia, mas, ao mesmo tempo, tenta-se mostrar que, ao se discutir o tema da juventude em seus fundamentos, dá-se primazia à Filosofia da Educação. E ao traçar as características dessa fase da vida, encontra-se no diário uma maneira de buscar definições gerais da natureza do que é ser jovem. Neste sentido, juventude é também postura de vida e liberdade de pensamento.

Diante dessa perspectiva sobre o diário, não espanta o grau de especulação filosófico-educacional utilizada por Benjamin no ensaio Metafísica da juventude, quando ele descreve a relação íntima em que o jovem está submetido quando exercita uma escrita sobre si mesmo. O tempo, a memória, a história, o eu, a autoformação, a cultura, o destino, a paisagem, o amor: são todas instâncias da vida evocadas pelo filósofo para produzir a manifestação de um eu oculto $^{7}$ na trajetória da vida passada e presente, no movimento da

\footnotetext{
${ }^{7}$ Cf. Assim como as reflexões sobre o eu da juventude em Benjamin, Fichte elabora a ideia de um eu absoluto em suas Preleções sobre "o destino do erudito", na tentativa de responder "qual a destinação do homem em geral, e através de quais meios ele pode alcançá-la da maneira mais segura". Para isso, o homem deve ser fiel àquilo que ele chama de "eu puro" e cuidar para que o seu "eu empírico", que é determinado pelas coisas do mundo, não o deixe de ser fiel a si mesmo. Portanto, a destinação do homem e sempre buscar a unidade de si mesmo: “(...) O eu puro nunca pode estar em contradição consigo mesmo, pois não há nele diversidade alguma, e é continuamente um e o mesmo; mas o Eu empírico, determinado e determinável pelas coisas

Doutora em Educação. Professora substituta na Universidade Federal de Santa Catarina.
} Brasileira, residente em Florianópolis - SC.Email: priscillastuarts@gmail.com 
consciência que se examina no momento da escrita, na confissão de atos e recordação de memórias de uma história pessoal, fruto de diversas circunstâncias vivenciadas, mas também um momento de elaborar a memória da infância, que é o tempo passado da história do jovem até então. O diário, de alguma forma, mostra que a formação não está restrita às instituições escolares e acadêmicas, indicando, portanto, a necessidade de se pensar acerca do potencial autoformativo quando se trata da escrita de um diário.

Como o clássico livro de Charlotte Bühler mostra ao analisar o diário de diversos jovens, acontece pela primeira vez a descoberta do sentido que há na ideia de formar, de elaborar a própria vida através e pela escrita, e, de maneira inédita, o jovem "adquire vivência de si próprio em sua unidade e totalidade, reúne em si passado e futuro, apreendendo sua existência historicamente". A autora ainda afirma que as memórias da infância, fruto de uma história de vida que se acumula, são um assunto recorrente nos conteúdos desses diários entre os jovens analisados (BÜHLER, 1980, 51). Essa afirmação lembra as memórias de Proust vividas pelo seu personagem em Combray, em sua monumental obra Em busca do tempo perdido (1913-1927).

A questão que está em Proust - entre tantas outras que Benjamin elabora - é a ideia de que o diário, de alguma forma, consegue expandir e problematizar a seguinte questão: "em que tempo vive o ser humano?" De alguma maneira, a questão do tempo é colocada de uma forma bastante peculiar, pois demonstra a imortalidade das ideias, dos pensamentos e das ações quando se está, na verdade, diariamente imerso no turbilhão de acontecimentos completamente desprovidos de magnitude, brilho e transcendência. A vida dos acontecimentos mundanos e rotineiros mergulha os seres na fatuidade do tempo, esvaziado pelo relógio das horas ordinárias, dispersas em sua homogeneidade. Portanto, no universo da juventude, quando ela está imersa nessa realidade desprovida do maravilhoso e do extraordinário, não consegue "ouvir a melodia de sua

externas, pode contradizer-se; - e sempre que se contradiz, isto é um sinal seguro de que não está determinado por si mesmo, segundo a forma do Eu puro, mas pelas coisas exteriores. Isto não deve ser assim, pois o homem é o seu próprio fim; ele deve determinar-se a si mesmo e nunca se deixar determinar por algo estranho (...). A destinação última de todos os seres racionais finitos é, portanto, a absoluta unidade, a contínua identidade, a inteira concordância consigo mesmos" (FICHTE, 2009, 22). 
juventude". Infelizmente, esse tempo precioso só será percebido quando a época da juventude se afastar, pois quando se está nesse momento próspero da existência, não se "intui" a necessidade de elaborar o tempo esquecido da infância no presente (BENJAMIN, 2010a, 99-100; cf. G.S. II, 1, 96-97).

O diário, que no idioma alemão é nomeado pelo termo Tagebuch, ou seja, o "livro do dia", aponta para o fato de que cada momento vivido é a oportunidade para aproveitar o espaço de liberação da vontade de juventude, que está presa ao cotidiano das vivências sem glória e sem transcendência. $\mathrm{O}$ diário, portanto, é o momento da suspensão do tempo finito, introduzindo a imortalidade no espaço em que o jovem elabora pela linguagem a confissão de suas vivências. Ele é ainda o lugar no qual "o eu mesmo começou a irradiar". A juventude é um rasgo no tempo cronológico, semelhante a um lampejo, a um raio. Mas esse raio não é "a interioridade turva daquele ser vivente que me chama eu e que me atormenta com suas familiaridades, mas um raio que vem daquele outro ser que parecia me oprimir, e que eu mesmo sou: raio do tempo". O tempo é sinônimo do eu, condicionado pela singularidade do jovem: "esse eu é tempo" (BENJAMIN, 2010a, 100; cf. G.S. II, 1, 97-98).

O tempo, em sua acepção comum, segundo Rosenfeld e Guinsburg, é uma dimensão negada pelos românticos; o tempo regular tão apreciado pelo espírito alemão que valoriza sobremaneira às regras dispostas sobre o seu domínio. Ocorre que "o romântico não vê sentido em cultivá-lo. Na realidade, gostaria de anulá-lo no sono eterno ou pelo menos esquecê-lo na sonolência constante" (ROSENFELD e GUINSBURG, 2013, 283). Isso significa que as reflexões de Benjamin refletem bastante seu espírito romântico, pois ele pensa esse elemento como algo da ordem da singularidade, da formação do eu. Para Rosenfeld e Guinsburg, essas noções aparecem bem marcadas no idealismo de Kant e Fichte. A abordagem sobre o diário, dessa forma, é confluente com essa mentalidade, pois é uma tentativa de simbolizar o “'eu' [como] construtor do mundo". "Não se trata naturalmente de nosso 'eu' pessoal, mas no íntimo de cada um de nós, de nosso 'eu' psíquico, dinâmico, mais ou menos biográfico, há uma força espiritual, por assim dizer, comum a todos, que produz o mundo" (ROSENFELD e GUINSBURG, 2013, 283). 
A juventude é o primeiro momento decisivo da vida em que se constrói uma narrativa, quando se é capaz de elaborar pela linguagem a história das próprias vivências. Mas não é apenas uma primeira forma de memória de histórias cotidianas, dado que escrever simples historietas de assuntos cotidianos não fabrica aquilo que Benjamin quer afirmar, ou seja, não constitui a juventude enquanto momento especial da vida, pois é um momento específico para ser singularizado frente à vida.

A infância é uma etapa, fase de pura imaginação, é um período no qual não há propriamente memória do passado, mas puro presente dos acontecimentos, em que os objetos e o mundo são quase que a extensão da própria criança. $O$ jovem, pelo contrário, tem a oportunidade de, pela linguagem, pela manifestação do tempo na narrativa, explorar o lado oculto da existência, pois consegue, pela memória, se distanciar do presente, recorrendo ao passado na construção de sua singularidade, exercendo um poder sobre aquilo que virá em seu futuro.

Esse tempo imortal que transcende as horas ordinárias expressadas no relato desse "livro do dia" depende da capacidade de elaboração de uma narrativa. Mas como cultivar a capacidade de elaborar a memória pelo uso da linguagem na construção da narrativa se o ser está, segundo o diagnóstico de Benjamin em seu ensaio da maturidade ${ }^{8}$, exposto aos infortúnios de um presente desagregador, impossibilitando a capacidade de elaborar o passado?

O diário talvez seja um tipo de confissão do eu que procura a liberdade, pois a linguagem é uma maneira de atravessar a esfera imanente do tempo, inserindo a todos em uma dimensão "suspens[a], suspendendo um eu que age nele - [no tempo]; [nesse instante me encontro] completamente transportado para o tempo, que me irradia precisamente". Pois se os seres vivem em um tempo carregado de profanidade, marcado por acontecimentos sem precedentes na história, o diário, para Benjamin, significa o nascimento de um tempo imortal, de um tempo puro, que na morte ganha significado. O filósofo ainda afirma que o tempo é essência, enquanto que o diário o imortaliza. Nesse eu-tempo, imortalizado pela linguagem, encontra-se, portanto, uma espécie de totalidade que é possível graças ao distanciamento da matéria do que se escreve,

\footnotetext{
${ }^{8}$ Cf. O narrador - ensaio sobre Nikolai Leskov.
} 
instaurando o silêncio e a onipotência que é a distância das coisas (BENJAMIN, 2010a, 100-101; cf. G.S. II, 1, 98).

Essa totalidade do eu-tempo, imortalizado pela escrita, poderia ser chamada de Jetztzeit, conceito utilizado no último ensaio de Benjamin. Um "tempo de agora" atravessado pelas três dimensões da temporalidade: presente, passado e futuro não lineares, cronológicos, mas marcados pela espacialidade da escrita que condensa a história na linguagem formativa do eu. O jetztzeit de Benjamin é chamado de "modelo do tempo messiânico" (BENJAMIN apud LÖWY, 2010, 138-139), que nas teses é definido como um momento de libertação da história, um instante em que a humanidade é redimida da linearidade do tempo. Como Löwy lembra, esse é um conceito que representa uma mônada, já que, segundo Benjamin, seria um "cristal da totalidade dos acontecimentos" (BENJAMIN apud LÖWY, 2010, 138-139). Como se percebe, esse é um dos termos centrais na filosofia da história do berlinense, e se coaduna com $A$ vida dos estudantes, em que ele afirma ser a vida dos mesmos o "reflexo de um momento mais elevado e metafísico da história". E é no "sistema", ou seja, no Estado, na dimensão da historicidade, que será possível "libertar o vindouro de sua forma desfigurada, reconhecendo-o no presente. Somente para isso serve a crítica" (BENJAMIN, 2009a, 31-32; cf. G.S.II, 1, 75).

Essa parece uma definição que contradiz o traço idealista do jovem Benjamin, mas é sabido que sua obra é permeada de paradoxos, de conceitos aparentemente contrastantes, os quais, em seus ensaios, funcionam como meios para operar e tratar das contradições ${ }^{9}$ típicas da modernidade. A valorização da dimensão da história em Benjamin simboliza seu olhar atento à dimensão da totalidade e da unidade da experiência humana.

Continuando a explanação sobre o conteúdo do diário, nele se encontra o nosso destino, já que, para Benjamin, todos ressuscitam e nascem novamente

\footnotetext{
9 Seligmann-Silva, na seção Idealismo, realismo e imaginação, de seu livro Ler o livro do mundo, desenvolve a relação de Benjamin com os românticos de Jena, sobretudo Schlegel e Novalis. Em uma passagem específica, mostra como as contradições (ou oximoros), são os modos mais lúcidos de operar com uma realidade contingente: "Os românticos defenderam uma razão analógica, um procedimento que mesclava o trabalho do conceito ao das imagens, a filosofia à retórica, unia a poesia à filosofia, e ainda incorporava um conceito paradoxal de verdade (ou Absoluto) que tentava pôr lado a lado o ideal e o histórico. Novamente o romantismo nos faz lembrar a figura do oxímoro" $(1999,59)$.
}

Doutora em Educação. Professora substituta na Universidade Federal de Santa Catarina. Brasileira, residente em Florianópolis - SC. Email: priscillastuarts@gmail.com 
a partir dos acontecimentos que vivenciam. Essa ressurreição acontece na paisagem, em meio à natureza. $E$ esse parece ser outro traço romântico do jovem filósofo, pois, similar à contemplação da natureza realizada pelo Arco-íris em uma paisagem de montanhas (Gebirgslandschaft mit Regenbogen), pintura de Caspar David Friedrich, o eu é enaltecido quando os sentidos são envolvidos pela natureza ao redor: "a paisagem nos leva ao seu meio; os topos das árvores nos atacam levantando questões; os vales nos cercam com seu nevoeiro e casas inconcebíveis nos cercam de formas. Tudo isso acontece justamente a nós, que somos seu centro" Para Benjamin, a natureza é parte de algo que já fomos, de um passado distante, enquanto a infância prova isso como uma profecia, como uma revelação daquilo que já fomos. E uma vez que pertencemos ao futuro da natureza, portanto, "a paisagem nos recebe - aos maiores - na desnudez do futuro" (BENJAMIN, 2010a, 102-103; cf. G.S. II, 1, 99-100).

Com uma linguagem carregada de misticismo, Benjamin revela que o diário oferece a fórmula para entender a relação de pertencimento e de afastamento do homem frente à natureza. E é no diário que se confronta esse passado com o futuro, que se aprende a conhecer a essência do próprio eu como entidade corpórea e espiritual (BENJAMIN, 2010a, 102-103; cf. G.S. II, 1,99-100).

A constituição dos homens revela que, quando se lida com o resultado das vivências individuais, se lida não apenas com uma juventude, mas com inúmeras juventudes. Isso significa que são várias as camadas possíveis de compreensão desse momento da vida, mas aqui se pensa, acima de tudo, nos fundamentos últimos do que é ser jovem, enquanto que as variáveis sociológicas e históricas, por exemplo, são fruto de diferenças culturais, que dizem respeito apenas a comportamentos e que não revelam, em última instância, a natureza do que é ser jovem.

Para entender essa natureza flutuante e demasiadamente peculiar, difícil de apreender em números, gráficos e estatísticas, recorre-se a um elemento bastante relevante que ajuda a refletir sobre a natureza da juventude e de sua tarefa, a saber, pela ironia romântica. Ao se tratar de um momento no qual a rebeldia é o guia e a necessidade da autoafirmação da própria individualidade, a necessidade de mostrar um modo próprio de ser no mundo, demonstrando a própria singularidade que domina o sentido das ações e dos pensamentos, da 
vida em última instância, a ironia significa a capacidade de afastamento de uma realidade homogênea, a negação de tudo que está estabelecido e discutido, sobretudo no ensaio Experiência, de Benjamin.

Ao falar sobre o diário, essa discussão é inserida porque é ali que a linguagem representa o jovem, sua potência, um rasgo no tempo, uma discussão tão relacionada ao âmbito que transcende os limites da própria comunicação comum que, ao empregá-la, ou seja, a ironia para Schlegel, é "como uma abertura para a reflexão, para o ato reflexionante, que é uma forma de aproximarse do absoluto, do incondicionado, daquilo que ainda não é - verdade alheia a toda definição" (SCHEEL, 2010, 59).

A ironia, no contexto do romantismo alemão ${ }^{10}$, ainda segundo Schlegel, irá representar a união entre a filosofia e a poesia - convém lembrar-se de seu sentido enquanto criação. A poesia, ao transcender o gênero literário, remete a reflexões da ordem do incomensurável, sobretudo em assertivas como esta: "a razão é apenas uma e, em todos, a mesma; mas, assim como todo indivíduo tem sua própria natureza e seu próprio amor, também cada um traz a própria poesia dentro de si” (SCHLEGEL, 2016, 483). Na esfera da juventude defendida por Benjamin, é possível aplicar a ironia como um método, uma comunicação que ajudará o jovem a encontrar, através de sua escrita, os fundamentos do que é ser jovem.

Para situar o contexto da discussão sobre o tema nos românticos com as ideias de Benjamin, vale lembrar, como é sabido, que a ironia é retomada e ganha forma no pensamento de Schlegel, mas é necessário ressaltar que, ao retomar à ironia socrática, Benjamin a amplia significativamente, inserindo-a no contexto das discussões modernas sobre a obra de arte. Para ele, a ironia socrática deve ser o mote que direciona a discussão sobre o tema e que está associada à ideia de crítica de arte. Para o artista, a crítica será fundamental em sua criação. O jovem como o protótipo do artista, ao guiar sua existência, no

\footnotetext{
10 Em Schelling, há também uma relação entre a ironia e o divino, pois ele "concebe um divino fundamentalmente irônico que opera de forma sempre simulada - que triunfa, por exemplo, exatamente ao morrer na cruz entre ladrões (...). E com isso, a ironia para Schelling é divina" (SCHELLING, XII-XIII, 1984).
}

Doutora em Educação. Professora substituta na Universidade Federal de Santa Catarina. Brasileira, residente em Florianópolis - SC. Email: priscillastuarts@gmail.com 
momento da escrita, pelo exemplo do gênio, percebe em sua vida um destino, revelado pela escrita de si.

Essas relações ficam mais esclarecidas quando Seligmann-Silva discute a forma de linguagem que melhor apresenta essas ideias, ou seja, para ele, "a ironia vincula-se nos românticos ao fragmento, à consciência do limite e da impossibilidade de se atingir o absoluto. Ela implica uma alternância entre os opostos, entre o absoluto e o singular" (SCHEEL apud SELIGMANN-SILVA, $2010,59)$. Ainda que consciente da impossibilidade de alcançar essa linguagem e expressão do pensamento compreendida como absoluto, a ironia, de alguma forma, toca nesse incomensurável pelo pensamento, nesse ideal de perfeição que todos buscam se espelhar.

A ideia de um rasgo no tempo antes abordada se aproxima da relação entre os dois polos da realidade humana, pois há "um movimento tenso" no qual, de alguma forma a própria ironia é uma expressão dele, pois resulta em "uma interrupção, uma pausa, "um momento no processo incessante da reflexão no seu movimento de alternância - pois existe reflexão sem esse movimento e, para os românticos, como Benjamin o notou, não existe ser fora da reflexão" (SCHEEL apud SELIGMANN-SILVA, 2010, 59-60).

Szondi define a personalidade daquele que se utiliza da ironia, acrescentando ideias muito significativas para entender a postura do jovem, a saber:

\footnotetext{
O sujeito da ironia romântica é o isolado que volta sobre si mesmo e a quem a consciência roubou a capacidade de ação. Ele aspira à unidade e ao infinito, o mundo aparece a ela alcantilado e finito. O que é denominado de ironia é a tentativa de enfrentar a sua situação crítica por meio do distanciamento e da desvalorização. Ele ambiciona ganhar um ponto de vista fora de si através da reflexão sempre mais elevada à potência para superar no nível da aparência a fenda entre o seu eu e o mundo (SCHEEL apud SZONDI, 2010, 60).
}

O diário é uma forma de voltar-se para si mesmo, onde as palavras são uma expressão de seu mundo. A ironia romântica, representação da impossibilidade de comunicação entre o humano e o divino, está, portanto, relacionada à temporalidade. O jovem, como exposto acima, é um raio do tempo, ou seja, representa a quebra de uma temporalidade uniforme, homogênea. A 
juventude, pelo diário, institui um rasgo no tempo, e isso significa a construção de si mesmo, a fabricação de uma memória pessoal, pois o tempo ganha um sentido único dentro de uma cultura e da história humana. O diário, em última instância, representa a tentativa de construir um significado para a própria biografia.

Logo, a ironia, no Tagenbuch, serve como um elemento de rebeldia, de negatividade ao que está construído e estabelecido pela cultura vigente. Ela é consequência da luta pelo reconhecimento da própria identidade e singularidade, diante de si mesmo e do mundo. O diário, como expressão desse lugar novo na vida do jovem, dá testemunho dessa procura, busca de autoafirmação de si e do mundo pela negação do que está dado.

Ao unir a educação institucional - conhecida através da escola, da universidade e das disciplinas agregadoras de todo o conhecimento, como a história, a filosofia e as agremiações estudantis - com os aspectos não mensuráveis por essa educação formal, os quais constituem a singularidade humana - a saber, a relação com a natureza, a cultura e a metafísica -, percebese que o universo da juventude é um agregado de fatores que buscam explicar que ela representa essa força plástica, os ideais estéticos como elementos representativos do verdadeiro ideal humano de unidade e totalidade expressados pela juventude, essa hora, esse momento glorioso da vida em que é preciso se espelhar durante toda a trajetória humana permanentemente.

E esse espelho, de alguma maneira, pode ser fornecido pela literatura do diário, esse lugar onde a elaboração do eu é formadora, não no sentido de fornecer respostas prontas às questões que a vida ou a realidade não consegue responder, mas de tornar essa expressão do eu, de jovem, esse "absoluto", mais próximo dos humanos. Ao observar esses ideais estéticos representados pela juventude, é possível se tornar mais consciente e responsável pelo próprio processo de autoformação em qualquer fase da vida. Deste modo, a imaginação é o guia para se adentrar na esfera da juventude, já que ela introduz a semente ${ }^{11}$ - para usar uma metáfora de Novalis - em que germinará a ideia de humano.

11 "Tudo é semente" (NOVALIS, 2009, 159).

Doutora em Educação. Professora substituta na Universidade Federal de Santa Catarina. Brasileira, residente em Florianópolis - SC. Email: priscillastuarts@gmail.com 


\section{REFERÊNCIAS}

BALLESTER, Lluís; COLOM, Antonio J. Walter Benjamin: filosofia e pedagogia. São Paulo: Cortez, 2016.

BENJAMIN, Walter. A vida dos estudantes. In_ : Reflexões sobre a criança, o brinquedo e a educação. Trad. Marcus Vinicius Mazzari. São Paulo: Ed. 34, 2009a, p. 31-47.

. Aufsätze, Essays, Vorträge. In_ : Gesammelte Schriften. Band II-

1. Reihe: Suhrkamp Taschenbuch Wissenschaft, 2014.

Diálogo sobre a religiosidade do nosso tempo. In_ : 0

capitalismo como religião. Trad. Nélio Schneider. São Paulo: Boitempo, 2013a, p. 27-51.

. Escritos sobre mito e linguagem. Trad. Susana Kampff Lages e Ernani Chaves. São Paulo: Ed. 34, 2011.

O ensino de moral. In_: Reflexões sobre a criança, o

brinquedo e a educação. Trad. Marcus Vinicius. São Paulo: Ed. 34/Duas

Cidades, 2009b, p. 11-19.

. Metafísica de la juventud. In_ : Obras libro II. Vol. 1. Trad. Jorge Navarro Pérez. Madrid: Abada Editores, 2010a, p. 93-107.

. O narrador: considerações sobre a obra de Nikolai Leskov. In

Obras escolhidas. Magia e técnica, Arte e política. Trad. Sérgio Rouanet. São Paulo: Brasiliense, 2010b, p. 197-221.

O posicionamento religioso da nova juventude. In Reflexões sobre a criança, o brinquedo e a educação. Trad. Marcus Vinicius. São Paulo: Ed. 34/Duas Cidades, 2009c, p. 27-30.

Pensamientos sobre el «Festival» de Gerhardt Hauptmann. In

Obras libro II. Vol.1. Trad. Jorge Navarro Pérez. Madrid: Abada Editores, 2010c, p. 57-61.

. Romantismo: um discurso não proferido para a juventude escolar.

In__: O capitalismo como religião. Trad. Nélio Schneider. São Paulo:

Boitempo, 2013b, p. 53-57.

. Veladas literárias estudiantiles. In Obras libro II. Vol.1. Trad. Jorge Navarro Pérez. Madrid: Abada Editores, 2010d, p. 70-73.

BOLLE, Willi. A ideia de formação na modernidade, In_ : Guiraldelli Jr, P (org.). Infância, escola e modernidade. São Paulo: Cortez, 1997.

BUBER, Martin. Sobre comunidade. Trad. Newton Aquiles von Zuben. São Paulo: Perspectiva, 1987. 
BÜHLER, Charlotte. Vida psíquica do adolescente. Trad. Lya Luft. São Paulo: Mestre Jou, 1980.

CANTINHO, Maria João. Messianismo e revolução: a história secreta. EUA: Createspace Pub, 2016.

FICHTE, Johann Gottlieb. O destino do erudito. São Paulo: Hedra, 2009.

KANT, Immanuel. Resposta à pergunta: Que é o lluminismo? In_ : A paz perpétua e outros opúsculos. Trad. Artur Morão. Lisboa: Edições 70, 2015, p. 9-18.

LESSING, G.Ephraim. La educación del género humano. In_ : Escritos filosóficos e teológicos. Trad. Agustín Andreu Rodrigo. Madrid: Editora Nacional, 1982, p. 573-603.

LOWY, Michael. Walter Benjamin: aviso de incêndio. Uma leitura das teses "Sobre o conceito de história". Trad. Wanda Nogueira Caldeira Brant. Trad. das teses Jeanne Marie Gagnebin e Marcos Lutz Müller. São Paulo: Boitempo, 2005.

NOVALIS; JUSTO, José Miranda. Nota de rodapé. In_ : A cristandade ou a Europa e seleção de fragmentos. Trad. José Miranda Justo. Lisboa: Antígona, 2006, p. 31.

Pólen. Trad. Rodrigues Torres Filho. São Paulo, Iluminuras, 2009.

RILKE, Rainer Maria. Cartas a um jovem poeta. Trad. Pedro Süssekind. Porto Alegre: L\&PM, 2016.

ROSENFELD, Anatol; GUINSBURG, J. Um encerramento. In_: GUINSBURG, J. (org.). Romantismo. São Paulo: Perspectiva, 2013, p. 275-294.

SCHEEL. Márcio. Poética do romantismo: Novalis e o fragmento. São Paulo: UNESP, 2010.

SCHLEGEL, Friedrich. Conversa sobre poesia. In__: Fragmentos sobre poesia e literatura/Conversa sobre poesia. Trad. Constantino Luz de Medeiros e Márcio Suzuki. São Paulo: Editora da UNESP, 2016.

Iluminuras, 1997.

O dialeto dos fragmentos. Trad. Márcio Suzuki. São Paulo:

SCHLEIERMACHER, Friedrich. Sobre la religión. Trad. Arsenio Ginzo Fernández. Madrid: Tecnos, 1990.

SELIGMANN-SILVA, Márcio. Ler o livro do mundo. Walter Benjamin: Romantismo e crítica literária. São Paulo: Iluminuras, 1999.

SPRANGER, Eduard. Psicologia da juventude. Trad. Thomas Newlands Neto. Rio de Janeiro: Edições Bloch, 1970. 
TÖNNIES, Ferdinand. Comunidade e sociedade como entidades típico-ideais. In _ : FERNANDES, Florestan (Org.). Comunidade e sociedade. Leituras sobre problemas conceituais, metodológicos e de aplicação. São Paulo: Companhia Editora Nacional, 1973, p. 96-116. 